\title{
ANALISIS CURAH HUJAN UNTUK MEMBUAT KURVA INTENSITY-DURATION-FREQUENCY (IDF) DI KAWASAN KOTA LHOKSEUMAWE
}

\author{
Fasdarsyah \\ Dosen Jurusan Teknik Sipil, Universitas Malikussaleh
}

\begin{abstract}
Abstrak
Rangkaian data hujan sangat diperlukan dalam melakukan analisis hidrologi. Hujan sangat berhubungan dengan intensitas, durasi, kedalaman, dan frekuensi yang dinyatakan dalam bentuk kurva Intensity-DurationFrequency (IDF). Data curah hujan yang digunakan diperoleh dari Badan Meteorologi Kota Lhokseumawe menggunakan metode distribusi Normal, distribusi Log Normal, distribusi Log Person III, distribusi Gumbel. Hasil penelitian menunjukkan bahwa distribusi Gumbel sangat cocok dengan sebaran data di wilayah studi. Dalam penelitian ini curah hujan harian dihitung dengan analisis frekuensi yang dimulai dengan menentukan curah hujan harian maksimum rerata, kemudian menghitung parameter statistik untuk memilih distribusi yang paling cocok. Intensitas dihitung dengan mempergunakan metode mononobe. Kurva IDF dapat digunakan untuk menghitung banjir rencana dalam perancangan bangunan hidrolik dengan mempergunakan metode rasional.
\end{abstract}

Kata Kunci : Curah hujan, Intensitas, Durasi, Frekuensi

\section{Pendahuluan}

Peningkatan perkembangan dan kemajuan kota menyebabkan pengelolaan sumberdaya air menjadi kurang begitu diperhatikan sehingga dapat menyebabkan banjir. Peristiwa ini hampir setiap tahun berulang, namun permasalahan ini sampai saat ini belum terselesaikan, bahkan cenderung makin meningkat, baik frekuensinya, luasannya, kedalamnnya, maupun durasinya. Oleh karena itu, untuk mengantisipasi terjadinya banjir, maka dilakukan pengamatan terhadap hujan dan intensitas hujan per durasi tertentu.

Pada umumnya dilakukan perhitungan dengan menghubungkan intensitas dengan durasi dan frekuensi yang dapat diekspresikan dengan kurva IntensityDuration-Frequency (IDF). Tujuan penelitian ini untuk menganalis curah hujan di kawasan kota Lhokseumawe. Hasil penelitian berupa kurva IDF dapat dimanfaatkan untuk menghitung debit banjir rencana yang digunakan dalam perencanaan bangunan pengendali banjir.

\section{Tinjauan Kepustakaan}

\subsection{Intensitas-Durasi-Frekuensi-Curva}

Hujan adalah curahan atau jatuhnya air akibat peristiwa kondensasi dari atmosfer ke permukaan bumi dalam bentuk air, embun, kabut atau salju. Intensitas curah hujan adalah Jumlah hujan yang dinyatakan dalam tinggi hujan atau volume hujan tiap satuan waktu. Besarnya intensitas hujan berbeda-beda, tergantung dari lamanya curah hujan dan frekuensi kejadiannya. Intensitas hujan diperoleh dengan cara melakukan analisis data hujan baik secara statistik maupun 
secara empiris. Intensitas curah hujan dinotasikan dengan huruf I dengan satuan $\mathrm{mm} / \mathrm{jam}$. Besarnya intensitas curah hujan sangat diperlukan dalam perhitungan debit banjir rencana berdasar metode Rasional

Durasi adalah Lama kejadian hujan (menitan, jam-jaman, harian) diperoleh terutama dari hasil pencatatan alat pengukur hujan otomatis. Dalam perencanaan drainase, durasi hujan sering dikaitkan dengan waktu konsentrasi khususnya pada drainase perkotaan diperlukan durasi yang relatif pendek, mengingat akan toleransi terhadap lamanya genangan dan meliputi daerah yang tidak sangat luas.

Hujan yang meliputi daerah luas, jarang sekali dengan intensitas tinggi, tetapi dapat berlangsung dengan durasi cukup panjang. Frekuensi Intensitas Hujan adalah interval waktu rata-rata antara kejadian curah hujan yang mempunyai intensitas tertentu dengan kejadian curah hujan dengan intensitas yang sama atau lebih lebat.

Dalam proses pengalihragaman hujan menjadi aliran ada beberapa sifat hujan yang penting untuk diperhatikan, antara lain adalah intensitas hujan (I), lama waktu hujan (t), kedalaman hujan (d), frekuensi (f) dan luas daerah pengaruh hujan (A). Komponen hujan dengan sifat-sifatnya ini dapat dianalisis berupa hujan titik maupun hujan rata-rata yang meliputi luas daerah tangkapan (chatment) yang kecil sampai yang besar.

Analisis hubungan dua parameter hujan yang penting berupa intensitas dan durasi dapat dihubungkan secara statistik dengan suatu frekuensi kejadiannya.

Penyajian secara grafik hubungan ini adalah berupa kurva Intensity-DurationFrequency (IDF). Analisis intensitas-durasi-frekuensi (IDF) dilakukan untuk memperkirakan debit aliran puncak berdasarkan data hujan titik (satu stasiun pencatat hujan). Data yang digunakan adalah data hujan dengan intensitas tinggi yang terjadi dalam waktu singkat, seperti $5,10,25, \ldots \ldots, 120$ menit lebih. Untuk itu diperlukan data hujan dari stasiun puncak otomatis.

\subsection{Distribusi Frekuensi Curah Hujan}

Menurut Suripin (2004), tujuan analisis frekuensi data hidrologi adalah berkaitan dengan besaran peristiwa-peristiwa ekstrim yang berkaitan dengan frekuensi kejadiannya melalui penerapan distribusi kemungkinan. Analisis frekuensi ini didasarkan pada sifat statistik data kejadian yang telah lalu untuk memperoleh probabilitas besaran hujan di masa yang akan datang. Dengan anggapan bahwa sifat statistik kejadian hujan yang akan datang masih sama dengan sifat statistik kejadian hujan masa lalu.

Dalam ilmu statistik dikenal beberapa macam distribusi frekuensi (jenis sebaran atau analisis frekuensi) yang banyak digunakan untuk menentukan tinggi curah hujan rencana dalam analisa hidrologi ada empat jenis yaitu:

a) Distribusi Normal

b) Distribusi Log Normal

c) Distribusi Log-Person III

d) Distribusi Gumbel 
Menurut Widyasari (2005) untuk menentukan dugaan (hipotesa) distribusi (sebaran) data sesuai parameter statistik adalah sebagai berikut.

a. Distribusi Normal

Ciri khas distribusi Normal adalah:

- Skewness (Cs) $=0,00$

- $\operatorname{Kurtosis}(\mathrm{Ck}) \quad=3,00$

b. Distribusi Log Normal

Sifat statistik distribusi Log Normal adalah:

- $\mathrm{Cs}=3 \mathrm{Cv}$

$-\mathrm{Cv}>0$

c. Distribusi Gumbel

Ciri khas statistik distribusi Gumbel adalah:

- Cs $\leq 1,1396$

- $C k \leq 5,4002$

d. Distribusi Log-Pearson III

Sifat statistik distribusi ini adalah:

- $\mathrm{Cs}=0,00$

- $\mathrm{Ck}>4$ s.d 6

\subsubsection{Distribusi Normal}

Distribusi normal atau kurva normal disebut juga distribusi Gauss. PDF (Probability Density Function) distribusi Normal dapat dituliskan dalam bentuk rata-rata dan simpangan bakunya, sebagai berikut:

$$
P(X)=\frac{1}{\sigma \sqrt{2 \pi}} \exp ^{\left(\frac{-(\mathrm{x}-\mu)^{2}}{2 \sigma^{2}}\right)},-\infty<\mathrm{x}<\infty
$$

Keterangan $: \mathrm{P}(\mathrm{X})=$ Fungsi densitas peluang normal (ordinat kurva normal)

$\mathrm{X}=$ Variable acak kontinu

$\mu \quad=$ Rata-rata nilai

$\mathrm{X} \sigma=$ Simpangan baku dari nilai $\mathrm{X}$

Dalam pemakaian praktis, umumnya rumus tersebut tidak digunakan secara langsung karena telah dibuat tabel untuk keperluan perhitungan, dan juga dapat didekati dengan:

$$
K_{T}=\frac{X_{T}-\bar{X}}{S}
$$

Keterangan: $\mathrm{X}_{\mathrm{T}}=$ Perkiraan nilai yang diharapkan terjadi dalam periode ulang $\mathrm{T}$ Tahunan

$\mathrm{X}=$ Nilai rata-rata hitung variat

$\mathrm{S} \quad=$ Deviasi standar nilai variat

$\mathrm{K}_{\mathrm{T}} \quad=$ Faktor frekuensi (nilai variabel reduksi Gauss)

Analisis Curah Hujan Untuk Membuat Kurva Iintensity-Duration-Frequency (IDF) di Kawasan Kota Lhokseumawe - Fasdarsyah 


\subsubsection{Distribusi Log Normal}

Jika variabel $\mathrm{Y}=\log \mathrm{X}$ terdistribusi secara normal, maka $\mathrm{X}$ dikatakan mengikuti distribusi Log Normal. PDF (Probability Density Function) untuk distribusi Log Normal dapat dituliskan dalam bentuk rata- rata dan simpangan bakunya, sebagai berikut:

$$
P(X)=\frac{1}{X \sigma \sqrt{2 \pi}} \exp ^{\left(\frac{-\left(\mathrm{Y}-\mu_{Y}\right)^{2}}{2 \sigma_{Y^{2}}}\right)}
$$

Keterangan : $\mathrm{P}(\mathrm{X})=$ Peluang log normal

$\mathrm{X}=$ Nilai varian pengamatan

$\mu \mathrm{Y}=$ Nilai rata- rata populasi $\mathrm{Y}$

$\sigma \mathrm{Y}=$ Deviasi standar nilai variat $\mathrm{Y}$

Dengan persamaan yang dapat didekati:

$$
\begin{aligned}
& Y_{T}=\bar{Y}+K_{T} S \\
& K_{T}=\frac{Y_{T}-\bar{Y}}{S}
\end{aligned}
$$

Keterangan: YT = Perkiraan nilai yang diharapkan terj adi dengan periode ulang T-tahunan

$\mathrm{Y} \quad=$ Nilai rata- rata hitung variat

$\mathrm{S}=$ Deviasi standar nilai variat

$\mathrm{KT}=$ Faktor frekuensi, merupakan fungsi dari peluang atau periode ulang $Y$

\subsubsection{Distribusi Log Person III}

Tiga parameter penting dalam Log-Person Type III yaitu harga rata-rata, simpangan baku dan koefisien kemencengan. Yang menarik adalah jika koefisien kemencengan sama dengan nol maka perhitungan akan sama dengan log Normal.

Berikut ini langkah-langkah penggunaan distribusi Log -Person Type III:

- Ubah data kedalam bentuk logaritmis, $X=\log X$

- Hitung harga rata-rata:

$$
\log \bar{X}=\frac{1}{n}(\log X t)
$$

- Hitung harga simpangan baku:

$$
S=\sqrt{\frac{(\log X i-\log \bar{X})^{2}}{n-1}}
$$


- Hitung koefisien kemencengan

$$
C s=n \sum_{i=1}^{n} \frac{(\log X i-\log \bar{X})^{3}}{(n-1)(n-2)(n-3)}
$$

- Hitung logaritma hujan atau banjir periode ulang $\mathrm{T}$ dengan rumus:

$$
\log X t=\log \bar{X}+K . S
$$

$$
\text { Keterangan: } \begin{array}{ll}
\log \mathrm{X} & =\text { Harga rata- rata sampel } \\
\mathrm{S} & =\text { Harga simpangan baku } \\
\mathrm{G} & =\text { Koefisien kemencengan } \\
\mathrm{S} & =\text { Deviasi standar nilai variat } \\
\mathrm{K} & =\text { Faktor probabilitas }
\end{array}
$$

\subsubsection{Distribusi Gumbel}

Gumbel menggunakan harga ekstri m untuk menunj ukkan bahwa untuk setiap data merupakan data exponential. Jika jumlah populasi yang terbatas dapat didekati dengan persamaan:

$$
X t=\bar{X}+S . K
$$

Keterangan: $\mathrm{X}=$ Harga rata-rata sample

$\mathrm{S}=$ Nilai varian pengamatan $X$

Faktor probabilitas K untuk harga-harga ekstrim Gumbel dapat dinyatakan dalam

$$
K=\frac{Y t-Y n}{S n}
$$

Keterangan: $\quad \mathrm{Yn}=$ Reduced mean yang tergantung jumlah sampel/data ke-n

$\mathrm{Sn}=$ Reduced standard deviation, yang juga tergantung pada jumlah sampel/data ke-n

Ytr = Reduced variated, yang dapat dihitung dengan persamaan berikut ini:

$$
Y t=-\ln \left(\ln \left(\frac{T r-1}{T r}\right)\right)
$$

\subsection{Intensitas hujan}

Intensitas hujan adalah jumlah hujan yang dinyatakan dalam tinggi hujan atau volume hujan tiap satuan waktu atau bisa dikatakan dengan ketinggian hujan yang terjadi pada suatu kurun waktu air hujan terkonsentrasi. Intensitas hujan diperoleh dengan cara melakukan analisis data hujan baik secara statistik maupun secara empiris. Apabila data hujan jangka pendek tidak tersedia, yang ada hanya 
data hujan harian, maka intensitas hujan dapat dihitung dengan menggunakan rumus Mononobe berikut ini:

$$
I=\frac{R_{24}}{24}\left(\frac{24}{t}\right)^{2 / 3}
$$

Keterangan :

I = Intensitas hujan ( $\mathrm{mm} / \mathrm{jam})$

$\mathrm{t}$ = lamanya hujan (menit) atau (jam)

$\mathrm{R}_{24}=$ Curah hujan maksimum harian (selama 24 jam) (mm)

Pada intensitas hujan terdapat lengkung intensitas hujan yaitu grafik yang menyatakan hubungan antara intensitas hujan dengan durasi hujan, hubungan tersebut dinyatakan dalam bentuk lengkung intensitas hujan dengan Periode Ulang hujan tertentu

\section{Metode Penelitian}

Penelitian ini dilakukan dengan cara pengumpulan data, analisa hidrologi berdasarkan curah hujan maksimun sehingga untuk mendapatkan kurva IDF langkah-langkah analisis dilakukan sebagai berikut:

1. Menentukan hujan harian maksimum untuk tiaptiap tahun data.

2. Menentukan parameter statistik dari data yang telah diurutkan dari kecil ke besar, yaitu: Mean $x$, Standard Deviation $\mathrm{S}$, Coeffisient of Variation $\mathrm{C}_{\mathrm{v}}$, Coeffisient of Skewness $\mathrm{C}_{\mathrm{s}}$, Coeffisient of kurtosis Ck.

3. Menentukan jenis distribusi yang sesuai berdasarkan parameter statistik yang ada.

4. Digambarkan pada kertas probabilitas dan tarik garis teoritik di atas gambar yang ada.

5. Lakukan pengujian dengan Chi-Kuadrat dan Smirnov Kolmogorov untuk mengetahui apakah jenis distribusi yang dipilih sudah tepat.

6. Dari jenis distribusi terpilih dapat dihitung besaran hujan rancangan berdasarkan periode ulang 2, 5, 10, 20, 50 dan 100 .

7. Menentukan intensitas curah hujan harian dengan metode Mononobe dalam kala ulang tertentu.

8. Penggambaran lengkung intensitas curah hujan harian dengan kala ulang tertentu.

\section{Analisis dan Pembahasan}

\subsection{Curah Hujan Rencana}

Data Curah Hujan diperoleh dari BMKG (Badan Metereologi, Klimatologi dan Geofisika) Lhokseumawe dari tahun 2003 sampai 2012 seperti diperlihatkan pada Tabel 4.1

Analisis Curah Hujan Untuk Membuat Kurva Iintensity-Duration-Frequency (IDF) di Kawasan Kota Lhokseumawe - Fasdarsyah 
Tabel 4.1 Data Curah Hujan

\begin{tabular}{|r|r|r|}
\hline \multicolumn{1}{|c|}{ Tahun } & Jumlah & Rerata \\
\hline 2003 & 559,80 & 46,65 \\
\hline 2004 & 455,30 & 37,94 \\
\hline 2005 & 508,30 & 42,36 \\
\hline 2006 & 490,00 & 40,83 \\
\hline 2007 & 457,60 & 38,13 \\
\hline 2008 & 347,80 & 28,98 \\
\hline 2009 & 612,10 & 51,01 \\
\hline 2010 & 693,60 & 57,80 \\
\hline 2011 & 500,10 & 41,68 \\
\hline 2012 & 451,40 & 37,62 \\
\hline
\end{tabular}

Data curah hujan yang diperoleh dari BMKG Lhokseumawe selama 10 tahun terakhir akan di analisis terhadap 4 (empat) metode analisa distribusi frekuensi hujan yang ada seperti diperlihatkan pada Tabel 4.2.

Tabel 4.2.Rekapitulasi Analisa Curah Hujan Rencana Maksimum

\begin{tabular}{|c|c|c|c|c|c|}
\hline No & $\begin{array}{c}\text { Periode ulang } \\
\text { (tahun) }\end{array}$ & Normal & Log normal & Log person III & Gumbel \\
\hline 1 & 2 & 94,5 & 93,32 & 95,50 & 107,745 \\
\hline 2 & 5 & 106,65 & 107,15 & 104,71 & 124,967 \\
\hline 3 & 10 & 113,02 & 114,81 & 114,81 & 136,398 \\
\hline 4 & 20 & 118,23 & 120,23 & 123,03 & 147,395 \\
\hline 5 & 50 & 124,16 & 128,82 & 144,54 & 161,576 \\
\hline 6 & 100 & 128,22 & 134,90 & 162,18 & 172,284 \\
\hline
\end{tabular}

\subsection{Jenis Distribusi}

Berikut ini adalah perbandingan syarat-syarat distribusi dan hasil perhitungan analisa frekuensi curah hujan seperti diperlihatkan pada Tabel 4.3.

Tabel 4.3 Perbandingan Syarat Distribusi Dan Hasil Perhitungan

\begin{tabular}{|c|l|l|c|}
\hline No & \multicolumn{1}{|c|}{ Jenis Distribusi } & \multicolumn{1}{|c|}{ Syarat } & Hasil Perhitungan \\
\hline 1 & Normal & $\mathrm{Cs}=0$ & $0,766 \neq 0$ \\
\hline 2 & Log Normal & $\begin{array}{l}\mathrm{Cs}=3 \mathrm{Cv} \\
\mathrm{Cv}<0,8325\end{array}$ & $0.766<0,8325$ \\
\hline 3 & Log-Person tipe III & $\mathrm{Cs} \approx 0$ & $0.766>0$ \\
\hline 4 & Gumbel & $\mathrm{Cs} \leq 1,1396$ & $0.766<1,1396$ \\
$\mathrm{Ck} \leq 5,4002$ & $3.928<5,4002$ \\
\hline
\end{tabular}




\subsection{Uji Kecocokan Jenis Sebaran}

Pengujian kecocokan sebaran berfungsi untuk menguji apakah sebaran yang dipilih dalam pembuatan duration curve cocok dengan sebaran empirisnya seperti diperlihatkan pada Tabel 4.4.

Tabel 4.4 Perhitungan Uji Chi-Kuadrat

\begin{tabular}{|l|c|c|c|c|c|}
\hline No & Interval Curah Hujan & $\begin{array}{c}\text { Frekuensi } \\
\text { pengamatan } \\
\text { Of }\end{array}$ & $\begin{array}{c}\text { Frekuansi } \\
\text { Teoritis } \\
\text { Ef }\end{array}$ & $(\text { Of - Ef })^{\mathbf{2}}$ & $(\text { Of - Ef) })^{\mathbf{2}} / \mathbf{E f}$ \\
\hline 1 & $68,215 \leq \mathrm{X} \leq 83,785$ & 2 & 2,5 & 0,25 & 0,1 \\
\hline 2 & $83,785 \leq \mathrm{X} \leq 99,355$ & 4 & 2,5 & 2,25 & 0,9 \\
\hline 3 & $99,355 \leq \mathrm{X} \leq 114,925$ & 3 & 2,5 & 0,25 & 0,1 \\
\hline 4 & $114,925 \leq \mathrm{X} \leq 130,495$ & 1 & 2,5 & 2,25 & 0,9 \\
\hline \multicolumn{7}{|c|}{ Jumlah } \\
\hline
\end{tabular}

Dari hasil perhitungan di atas didapat nilai $\mathrm{X}^{2}$ sebesar 2 yang kurang dari nilai $\mathrm{X}^{2}$ pada tabel uji Chi-Kuadrat yang besarnya adalah 5,991. Maka dari pengujian kecocokan penyebaran Distribusi Gumbel dapat diterima.

Untuk mendapatkan intensitas hujan jam - jaman dari data curah hujan harian digunakan rumus mononobe seperti pada persamaan (2.12). Hasil analisis ditunjukkan dalam tabel 4.5.

Tabel 4.5 Intensitas hujan jam-jaman (mm/jam) untuk berbagai periode ulang

\begin{tabular}{|c|c|c|c|c|c|c|}
\hline \multirow{2}{*}{$\begin{array}{c}\mathrm{t} \\
\text { (menit) }\end{array}$} & \multicolumn{6}{|c|}{ Kala Ulang (Tahun) } \\
\cline { 2 - 7 } & 2 & 5 & 10 & 20 & 50 & 100 \\
\hline 5 & 195,8 & 227,1 & 247,9 & 267,8 & 293,6 & 313,1 \\
\cline { 2 - 7 } 10 & 123,3 & 143,1 & 156,1 & 168,7 & 185,0 & 197,2 \\
\cline { 2 - 7 } 15 & 94,1 & 109,2 & 119,2 & 128,8 & 141,1 & 150,5 \\
\cline { 2 - 7 } 30 & 59,3 & 68,8 & 75,1 & 81,1 & 88,9 & 94,8 \\
\cline { 2 - 7 } 45 & 45,3 & 52,5 & 57,3 & 61,9 & 67,9 & 72,4 \\
\cline { 2 - 7 } 60 & 37,4 & 43,3 & 47,3 & 51,1 & 56,0 & 59,7 \\
\cline { 2 - 7 } 120 & 23,5 & 27,3 & 29,8 & 32,2 & 35,3 & 37,6 \\
\cline { 2 - 7 } 180 & 18,0 & 20,8 & 22,7 & 24,6 & 26,9 & 28,7 \\
360 & 11,3 & 13,1 & 14,3 & 15,5 & 17,0 & 18,1 \\
\cline { 2 - 7 } 720 & 7,1 & 8,3 & 9,0 & 9,7 & 10,7 & 11,4 \\
\hline
\end{tabular}

Dari Tabel 4.5 dapat dibuat kurva Intensity Duration Frequency (IDF) seperti terlihat pada Gambar 4.1 


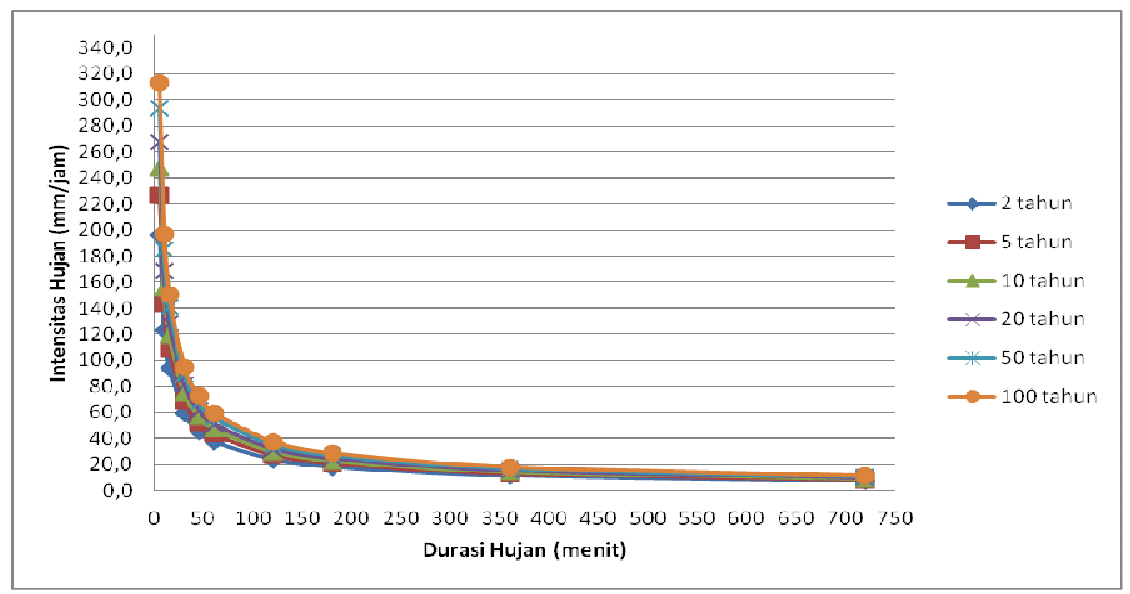

Gambar 4.1 Kurva Intensity - Duration - Frequency

\section{$5 \quad$ Kesimpulan}

Berdasarkan dari hasil penelitian dan pembahasan yang telah dilakukan maka dapat diambil beberapa kesimpulan sebagai berikut :

1. Sebaran data curah hujan harian maksimum rerata di Lhokseumawe mengikuti analisis distribusi Gumbel.

2. Berdasarkan analisis frekuensi untuk curah hujan rerata maksimum harian pada daerah Lhokseumawe ternyata hujan rancangan untuk periode ulang 2, 5, 10, 20, 50, dan 100 tahun adalah 107,745; 124,967; 136,398; 147,395; 161,576; $172,284 \mathrm{~mm}$.

3. Intensitas berhubungan dengan durasi dan frekuensi dapat diekspresikan dengan kurva Intensity-Duration-Frequency (IDF).

4. Kurva IDF dapat digunakan untuk menentukan banjir rencana dengan mempergunakan metode rasional.

\section{Daftar Kepustakaan}

1. Asdak, C. 1995. Hidrologi dan Pengelolaan Daerah Aliran Sungai, Gadjah Mada University Press, Yogyakarta

2. Chow, Ven Te. 1992. Hidrolika Saluran Terbuka, Penerbit Erlangga, Jakarta

3. Khatab, dkk., 2013, Evaluasi waduk pusong sebagai upaya pengendalian banjir di kota Lhokseumawe kabupaten Aceh Utara, Jurnal Teknik Sipil USU Vol. 2 No. 3

4. Soemarto, C.D. 1999, Hidrologi Teknik, Penerbit Erlangga, Jakarta

5. Sosrodarsono, S., dan Takeda. 1999, Hidrologi Untuk Pengairan, P.T. Pradnya Paramita, Jakarta

6. Sri Harto Br, 2000, Hidrologi Teori Masalah Penyelesaian, Nafiri, Jakarta

7. Suripin, 2004, Sistem Drainase Perkotaan Yang Berkelanjutan, Penerbit Andi Offset, Yogyakarta

8. Suroso, 2006, Analisis Curah Hujan untuk Membuat Kurva Intensity Duration Frequency (IDF) di Kawasan Rawan Banjir Kabupaten Banyumas, Jurnal Teknik Sipil Vol. 3 No. 1 Januari 2006.

9. Widyasari, T, 2005, Rekayasa Hidrologi, Universitas Yokyakarta 